Research Report No. 1974982

\title{
Whistleblowing and Freedom of Conscience: Towards a New Legal Analysis
}

Richard Haigh

Osgoode Hall Law School of York University, rhaigh@osgoode.yorku.ca

Peter Bowal

University of Calgary, bowal@ucalgary.ca

Follow this and additional works at: http://digitalcommons.osgoode.yorku.ca/clpe

Part of the Constitutional Law Commons, and the First Amendment Commons

\section{Recommended Citation}

Haigh, Richard and Bowal, Peter, "Whistleblowing and Freedom of Conscience: Towards a New Legal Analysis" (2012). Comparative Research in Law \& Political Economy. Research Paper No. 1974982.

http://digitalcommons.osgoode.yorku.ca/clpe/316 


\section{Whistleblowing and Freedom of Conscience: Towards a New Legal Analysis Richard Haigh and Peter Bowal}

\section{In matters of conscience the law of majority has no place.}

\section{- Mahatma Gandhi}

\section{Introduction}

Most of us have an instinctive understanding of what "whistleblowing" is: the act of alerting the public to scandal, danger, malpractice, corruption or other immoral or unethical behaviour. A whistleblower usually feels compelled to act where public interests in health, safety and security are in imminent peril. For a long time, whistleblowers were not recognized in a favouralbe light, often characterized as disloyal, traitors or tattletales who, rather than commended for acting constructively, were often belittled, treated as pariahs, forced to recant or even leave their jobs. Times have changed, and whistleblowers are now acknowledged, and sometimes even admired. There is still some way to go, however, to reach complete acceptance. We believe that a strongly developed freedom of conscience, as expressed in s. 2(a) of the Canadian Charter of Rights and Freedoms ${ }^{1}$ but distinct from freedom of religion, could go some way towards achieving that goal.

Beginning with the Reformation, conscience and religion have been strongly linked in Western thought, such that distinctions between them are often minimized. Martin Luther connected the two by claiming that an individual's belief or unbelief is a matter of conscience and that Catholics held only a "conscience in appearance" since their conscience

\footnotetext{
- Visiting Professor, Osgoode Hall Law School, York University and Professor, Haskayne School of Business, University of Calgary, respectively. Professor Bowal acknowledges generous financial support from the Canadian Bar Association Law for the Future Fund.

${ }^{1}$ Part I of the Constitution Act, 1982, being Schedule B to the Canada Act 1982 (U.K.), 1982, c.11. ("Charter").
} 
was not guided by Scripture. ${ }^{2}$ A few centuries later, John Stuart Mill, a philosopher normally given to careful parsing of concepts, nevertheless also appears to treat the two terms synonymously (or at least is indifferent to any distinction) when he asserts that the great writers of the past, espousing liberty, have relied on "freedom of conscience" to ensure that no one is accountable to another for a religious belief. ${ }^{3}$

Conscience is often treated as inseparable from religion, in other words, without any meaningful analysis of the relationship between the two. This is especially true in legal constitutional terms, where the elision usually comes at the expense of "conscience." At best then, conscience takes the form of a silent partner to religion. At worst, it is frequently ignored or unnoticed.

This need not be so. In this paper, we argue that the deliberate inclusion of "conscience" in s. 2(a) of the Charter ought to taken seriously; to do so, freedom of conscience must be recognized as an independent and robust freedom. A fully developed freedom of conscience might bring a less divisive, morality-based freedom into the foreground as the primary freedom, subsuming some forms of religious freedom within it.

Whistleblowing is an activity that seems to have some connection to conscience but not necessarily religion. If conscience is recognized as an independent freedom, separate from religion, its legal development may be best informed by an analysis of whistleblowing, and vice versa. In this article, we canvass how whistleblowing might be treated as a special form of activity that lends substance to an independent freedom of conscience under the Charter. Without developing a fully-fledged argument that freedom of conscience should be the default freedom, encompassing religious freedom in many cases, we argue that an

\footnotetext{
2 See Joseph Lecler, Toleration and the Reformation 2 vols. (New York: Association Press, 1960) quoting Luther's letter of Nov. 1525 or Feb. 1526 (at vol 1, 157-58).

3 On Liberty, (Toronto: Penguin, 1982) at 66-7.
} 
approach to freedom of conscience could be used for a more commonplace purpose, such

as a framework for accepting and recognizing the importance of whistleblowing and

lessening its stigma within society.

The paper sketches this idea out in three parts: we first briefly discuss whistleblowing and its development within a modern legal and business environment. We then explore the nature of a stand-alone legal and constitutional freedom of conscience, sketching out an argument for its singularity and importance. In the last part, we show how a revitalized freedom of conscience - distinct and separate from religious freedom - could provide a model for interpreting whistleblowing in Canada.

\section{Whistleblowing: History and Development}

Whistleblowing is an emerging sui generis field of law ${ }^{4}$ which integrates disparate elements of the law of privacy, labour and employment, civil procedure, ${ }^{5}$ contracts, ${ }^{6}$ ethics, defamation, the constitutional rights of expression and conscience, ${ }^{7}$ professional responsibility and administrative law, crimes, confidential information and privilege, business

\footnotetext{
4 The first known law school course in Canada focused entirely on the subject of whistleblowing was taught by Peter Bowal at the Faculty of Law, University of Western Ontario in January 2005.

5 The retaliatory civil lawsuit in defamation is a predictable response taken by the individual who is reported to have acted wrongly, to intimidate and punish whistleblowers. See, Peter Bowal, "The Whistleblower's Qualified Privilege Defence to Defamation," Academy of Legal Studies in Business, 79 ${ }^{\text {th }}$ Annual Conference, Ottawa, Ontario, August 18-21, 2004; and Terry Dworkin, Elletta Sangrey Callahan, Peter Bowal and David Lewis, "Whistleblowing and Defamation in the US, Great Britain and Canada," Annual Conference of the Academy of Legal Studies in Business in San Francisco, CA, August 2-6, 2005

In the United States, SLAPP (strategic lawsuits against public participation) rules and procedures may deter this retaliatory litigation. Canadian jurisdictions do not have SLAPP provisions. The Quebec government introduced a new law in 2009 to curb abusive civil proceedings, and the Uniform Law Conference of Canada is proposing a similar model act that could be applied in every province: Kevin Marron, 'SLAPP on the Wrist,' Canadian Lawyer, January 4, 2010.

Defendants, even those with valid defences, do not often find support in summary dismissal procedures. Ontario's summary judgment rule recently was significantly changed to encourage more litigants, such as whistleblower defendants, to dispose of actions before trial. In the recent case of Optech Inc v. Sharma (2011 ONSC 680), Justice David Brown set out a comprehensive critique of the Court's new powers under the revised rule, positing that the costs and complexities of litigation may now actually increase.

${ }^{6}$ One common issue is the enforceability of confidentiality clauses in the light of competing public policy interests.

7 Supra, note 1, s. 2(b) and 2(a), respectively.
} 
organizations and corporate governance, Codes of Conduct, dispute resolution and various regulatory instruments. ${ }^{8}$ Most of these legal elements are adapted to fit and serve de facto whistleblowing scenarios, such as whether a specific employee disclosure of employer wrongdoing to the media amounts to sufficient cause for summary dismissal.

On the other hand, some forms of legal ordering aim to encourage or protect whistleblowing more generally: criminal and regulatory legislation, for example, is purposebuilt for whistleblowing activity. These types of legislation come in two forms. The first form we call embedded whistleblowing legislation, where a collection of protective provisions is contained within an existing regulatory regime. ${ }^{9}$ There are many examples of embedded whistleblower protections in federal and provincial legislation across Canada, such as protection for employees who file complaints against their employers under human rights, occupational health and safety or environmental legislation. The second form we refer to as encompassing whistleblowing legislation. Encompassing legislation sets up a system or model to address and regulate whistleblowing in a larger, yet identifiable, sector of activity. Examples of this form of independent, comprehensive whistleblowing legislation are the federal Public Servants Disclosure Protection Act ${ }^{10}$ and the Manitoba Public Interest Disclosure (Whistleblower Protection) Act. ${ }^{11}$ While less prevalent than the embedded form of legislation,

\footnotetext{
8 The history, theory and law of whistleblowing in Canada is not highly organized in academic writing to date. Much of what has been published may be found on blogs, websites and disparate incident reports. Many of the principles and issues, although not the laws themselves, are universal. To this end, see Stephen M. Kohn, Concepts and Procedures in Whistleblower Law, (Westport, Connecticut: Quorum Books, 2001). The leading international not-for-profit organization, with a focus on state anti-corruption initiatives and international business is Transparency International, at http://www.transparency.org.

9 These auxiliary provisions do not "give employees the message that they are to be generalized watchdogs against organizational wrongdoing." Marcia P. Miceli and Janet P. Near, Blowing the Whistle: The Organizational and Legal Implications for Companies and Employees, (New York: Lexington Books, 1992) at 234.

10 S.C., 2005 , c. 46.

${ }^{11}$ C.C.S.M., c. P217. See also protective provisions for all employees in employment legislation, such as Employment Standards Act, S.N.B. 1982, c. E-7.2, s. 28(c) and the Labour Standards Act, R.S.S. 1978, c.L-1, s. 74(1) (as amended); and in Regulations applying to the public service only, such as the Civil Service Disclosure of
} 
encompassing legislation is more frequently enacted in response to a highly-publicized, and often politicized, scandal in the public sector. The goal is usually to detect and ultimately prevent such scandals in the future. ${ }^{12}$

The recent growth in whistleblowing legislation has its roots in Enron and similar corporate accounting frauds that occurred in the United States beginning in late 2001. This culminated in the omnibus Sarbanes-Oxley (SOX) legislative package ${ }^{13}$ to strengthen corporate governance and controls and responsibility over financial reporting of US-listed companies. Provincial securities regulators in Canada largely copied and imported these provisions to apply to the Canadian securities markets. ${ }^{14}$ Public sector whistleblowing legislation received its greatest impetus in early 2006 with the introduction of Bill C-2, the Federal Accountability $A c t,{ }^{15}$ by a new minority government that had just fought and won an election on the promise to "stand up for Canada" in the wake of the well known "sponsorship scandal” and Gomery Commission report. ${ }^{16}$ And yet, Canadian whistleblower protection legislation has both its proponents ${ }^{17}$ and detractors. ${ }^{18}$ Part of the problem has to

\footnotetext{
Wrongdoing Regulations, O.I.C. 2004-374, N.S. Reg. 205/2004, enacted pursuant Section 45 of the Civil Service Act, R.S.N.S. 1989 , c. 70 .

12 At the time of writing, a former government member of the Alberta legislature was alleging double bookkeeping and that health care professionals in Alberta were paid "in the millions" to remain silent about cancer patients dying on the wait lists. He refused to identify his sources until new whistleblower legislation granting him "complete immunity" was enacted: see, "Maverick MLA Alleges Cancer Death Cover-up" Calgary Herald (01 March 2011) A4.

13 Infra, note 58.

${ }^{14}$ See, infra, text accompanying footnote 61.

15 S.C. 2006 , c. 9.

${ }^{16}$ Gomery Commission Report, Vol 2, available at http://www.google.ca/url? sa=t\&source=web\&cd=1\&ved=0CBUQFjAA\&url=http $\% 3 \mathrm{~A} \% 2 \mathrm{~F} \% 2 \mathrm{Fdsp}-$ psd.pwgsc.gc.ca $\% 2$ FCollection $\% 2 F G o m e r y I I \% 2 F R e s e a r c h S t u d i e s 2 \% 2 F C I S P A A$ Vol2 3.pdf\&rct=j\&q=right doing $\% 20$ public $\% 20$ service $\% 20$ of $\% 20$ canada\&ei=UwCVTdW5MujiiALgppHlCA\&usg=AFQjCNETh9eciOX mzpi42xQ3DX1ALQjnTQ\&sig2=sVOQO7azVJ-YkbTL3uuTQQ\&cad=rja.

17 See, for example, Kenneth Kernaghan and John W. Langford, The Responsible Public Servant (Halifax: Institute for Research on Public Policy, 1990); Keith Archer, 'From Rhetoric to Reality: Protecting Whistleblowers in Alberta' (2005) (a Report prepared for the Parkland Institute www.ualberta.ca/parkland); Jonathan Carson, 'The Need for Whistleblowing Legislation in Canada: A Critical Defence' (2006) http://www.cpsa-acsp.ca/papers-2006/Carson.pdf; __, Whistleblowing in Canada: A New Framework of Analysis' (2008) http://www.cpsa-acsp.ca/papers-2008/Saunders.pdf; and FAIR (Federal Accountability Initiative for Reform), whose Mission Statement reads: "promotes integrity and accountability within
} 
do with understanding what is meant by whistleblowing. We turn now to definitions and other features of whistleblowing.

\section{(a) What is Whistleblowing?}

As noted above, "whistleblowing" describes a phenomenon which most people generally recognize. It is, however, difficult to capture in legal terms. For one, it is sufficiently lacking in formality to carry the load of a discrete subject of law. Accordingly, whistleblowing legislation often invokes other terminology such as making "disclosures" or "reports" in the context of the "public interest" and "integrity." 19 These terms are chosen to portray the activity in a more positive light. ${ }^{20}$

There is also little consensus as to the range of whistleblowing activity that merits legal protection. A narrow view limits whistleblowing to instances where public interests in health, safety and security are in imminent peril. This early form is well represented in Ralph Nader's 1979 definition as “ . . a an act of a man or woman who, believing that the public interest overrides the interest of the organization he serves, blows the whistle that the organization is involved in corrupt, illegal, fraudulent or harmful activity.",21

\footnotetext{
government by empowering employees to speak out without fear of reprisal when they encounter wrongdoing. Our aim is to support legislation and management practices that will provide effective protection for whistleblowers and hence occupational free speech in the workplace." Transparency International, which describes itself as "the global coalition against corruption" in November 2009 published 'Recommended Principles for Whistleblowing Legislation,' available from its website, http://www.transparency.org/. 18 Eg., Brian Martin, 'Illusions of Whistleblower Protection,' (2003:5) UTS L. Rev. at 119-130.

${ }^{19}$ The language of "rightdoing" has also emerged, particularly in the Public Service of Canada. See, eg., Kenneth Kernaghan, Encouraging "Rightdoing” and Discouraging Wrongdoing: A Public Service Charter and Disclosure Legislation" in the Gomery Commission Report, Vol 2, The Public Service and Transparency, at p. 73, supra, note 15.

${ }^{20}$ Some of the pejorative descriptors of the whistleblower include tattle-tale, traitor, nark, snitch, muckraker, unstable, turncoat, squealer, rat, informer, whiner, stool pigeon and spy. Other whistleblower-related conceptions are "shooting the messenger" and "bearer of bad news."

${ }^{21}$ Nader, Petkas, and Blackwell, Whistleblowing (1972), quoted in Nicholas M Rongine, 'Toward a Coherent Legal Response to the Public Policy Dilemma Posed by Whistleblowing' (1985) 23:2 Am. Bus. L. J. 28.
} 
A more liberal approach, which we favour, integrates more completely with conscience. This broader approach defines whistleblowing as the reporting of any wrongdoing to anyone inside or outside one's organization where any form of retaliation may be expected. It is the spectre and essence of retaliation in any form and degree which most saliently tests the limits of acting upon one's conscience.

While whistleblowing is about disclosure, the desire to inform must also serve a socially useful function. Unwanted disclosure bears the elemental quality of an indictment in that it identifies a wrongdoing and accuses and challenges a person or an organization. The indicting disclosures are made usually because the whistleblower feels possessed of insufficient authority over the wrongdoer and of power to effect change by other means. ${ }^{22}$ Jubb's widely-accepted definition includes this element: ${ }^{23}$

Whistleblowing is a deliberate non-obligatory act of disclosure, which gets onto public record and is made by a person who has or had privileged access to data or information of an organization, about non-trivial illegality or other wrongdoing whether actual, suspected or anticipated which implicates and is under the control of that organization, to an external entity having potential to rectify the wrongdoing.

Thus, reportable wrongdoing in whistleblowing legislation and corporate policies usually embraces one of the following, in declining order of seriousness: contravention of a law; an act or omission that creates a substantial danger to the life, health or safety of persons or to the environment; gross financial or other mismanagement (especially in public sector organizations); abuse of power such as conflicts of interest and harassment; serious breaches

\footnotetext{
22 Wim Vandekerckhove, Whistleblowing and Organizational Social Responsibility - A Global Assessment (Aldershot, England: Ashgate, 2006) at 22.

${ }^{23}$ Peter B. Jubb, 'Whistleblowing: A Restrictive Definition and Interpretation,' (1999) 21:1 J. Bus. Ethics 77 at 78.
} 
of an organizational code of conduct or other policy; an act of reprisal; ${ }^{24}$ and unethical behaviour. $^{25}$

In fact, it may be easier to define whistleblowing by its negative. As whistleblowing is anchored in verifiable wrongdoing, neither criticism nor outspoken dissent from the employer's policies is whistleblowing, although these may be protected forms of speech under the Charter ${ }^{26}$ or at common law. ${ }^{27}$ Likewise, generally poor management decisions or styles and even persistent managerial incompetence would not qualify as reportable "wrongdoing" under traditional legislative and corporate policy frameworks regulating whistleblowing.

In practice, legislators and drafters of corporate whistleblowing policies define the boundaries of reportable wrongdoing and the prescribed channels of reporting. These parameters control both whistleblowing and the scope of anti-retaliation protection.

\section{(b) The Venues and V alues of Whistleblowing}

If we conceive of whistleblowing as, in general, the reporting of wrongdoing, the contexts in which it may arise become equally expansive. The three principal venues in which whistleblowing may occur are the workplace, the competitive marketplace and atlarge, or qua citizen. All can interact directly with a person's conscience.

\footnotetext{
${ }^{24}$ In practice, whistleblowing often involves two wrongs: the original substantive wrong, and the cover-up or reprisal.

25 The whistleblowing cliché "speaking truth to power" dates to the publication of the pamphlet Speak Truth to Power by American Quakers in 1955, proposing a new approach to the Cold War. Since then the term has been frequently used in many different contexts. For example, Speaking Truth to Power (Doubleday, 1997) was the title of Anita Hill's book alleging sexual harassment by US Supreme Court Justice Clarence Thomas. 26 Alberta Union of Provincial Employees v. Alberta, 2002 ABCA 202; 312 A.R. 9; 218 D.L.R. (4th) 16; [2002] 11 W.W.R. 1; 5 Alta. L.R. (4th) 238.

27 Fraser v. P.S.S.R.B., [1985] 2 S.C.R. 455, 23 D.L.R. (4th) 122, 9 C.C.E.L. 233, 19 C.R.R. 152; 18 Admin. L.R. 72.
} 
The workplace, the most fertile source of whistleblowing reports, is the focus of most anti-retaliation legislation and corporate internal disclosure policies. ${ }^{28}$ The distinguishing features of workplace whistleblowing relate to the relational power differential and highly captive nature of the whistleblower. The full range of retaliation, inside and outside the workplace, may be applied against the whistleblowing employee in organizations which demand obedience, conformity and loyalty. At work, the whistleblower may not be viewed as trustworthy or a reliable team player and, in response, may be granted reduced access to information, facilities, consultation and decision-making. As a result of whistleblowing, one may receive critical performance appraisals, be denied raises and promotions, or passed over for discretionary bonuses, perquisites and for interesting work and future opportunities for further growth and development. Socially, the whistleblower may be ostracized at work, shunned and excluded. Many whistleblowers are disciplined at their place of employment, to the point of being demoted or terminated, even where they followed whistleblowing policies in effect and where their report of wrongdoing was accurate. They may be sued for defamation by the employer or by individuals whose conduct they have reported. ${ }^{29}$

Where a business reports on its competitor's law-breaking to an external regulator or to the media, it is engaging in competitive marketplace whistleblowing. This can also occur in more arm's length cases involving fiduciaries, agents or equivalents: for example, financial analysts, whose business it is to report to its clients the veracity of corporate financial positions in which those clients may be interested in investing, or third party

\footnotetext{
${ }^{28}$ For analysis of a public sector whistleblowing program, see Peter Bowal, "[Municipal] Whistleblowing Program is Working," Calgary Herald, March 07, 2009 http://www.calgaryherald.com/Whistle+blowing+working/1364639/story.html.

29 Alford found whistleblowers so isolated that few admitted they would do it again. See, C. Fred Alford, Whistleblowers: Broken Lives and Organizational Power (Cornell University Press, 2002).
} 
researchers, such as university academicians and investigative journalists, who investigate and report on events. Less personally captive, these whistleblowers are nevertheless more vulnerable to threats, withdrawal of resources and other support, campaigns to discredit the whistleblower, and retaliatory litigation.

Qua citizen whistleblowing occurs where civic-minded individuals, in their personal capacity, step forward and report wrongdoing in the form of crimes and other regulatory transgressions. These individuals may be motivated by social conscience, morality, selfpreservation, or financial reward ${ }^{30}$ in matters of public interest. Perhaps surprising to some, civilian personal investment in the public law enforcement system is significant. Most criminal and regulatory offences are voluntarily reported by informants and tipster witnesses. Given the practical and resource limitations on police and regulatory enforcement officials to detect infractions, civilians serve as the durable first reporting system where reports are filed, investigations are launched, prosecutions are conducted and laws are enforced.

Such civic involvement creates some risk for the reporter, although many legal protections exist. The criminal informant, for example, may be a compelled witness in court proceedings, ${ }^{31}$ and may face serious criminal contempt of court consequences for refusing to give evidence. ${ }^{32}$ On the other hand, the Criminal Code contains numerous provisions to protect informants and witnesses from retaliation at the hands of the accused criminal wrongdoer. Informations to Obtain Search Warrants, which often contain informant particulars, may be sealed by the Court, ${ }^{33}$ accused persons may be ordered on an undertaking or recognizance to initiate no contact whatsoever with the informant, ${ }^{34}$ publication of

\footnotetext{
30 The main source of compensation for criminal reporting is the non-profit organization Crimestoppers, discussed below.

31 The Criminal Code of Canada, R.S.C. 1985, c. C-46, ss. 698 to 700 (Criminal Code).

32 Ibid, s. 708.

33 Ibid, s. 487.2 .

34 Ibid, s. 515.
} 
witness identities may be barred, ${ }^{35}$ the public may be excluded where warranted, ${ }^{36}$ witnesses may testify behind a screen ${ }^{37}$ or outside of the courtroom, ${ }^{38}$ and cross examination may be limited. ${ }^{39}$ It is a crime in Canada to obstruct justice by interfering with witnesses ${ }^{40}$ and to impede the administration of justice. ${ }^{41}$ Ultimately in the most extreme instances of retaliation risk, informants of crimes are entitled to protection pursuant to the Witness Protection Program Act, ${ }^{42}$ administered by the Royal Canadian Mounted Police. ${ }^{43}$

Regardless of its venue, it is our view that the broad approach to whistleblowing provides both public and private benefits. ${ }^{44}$ At one level, whistleblowing gives voice to constitutional freedoms such as conscience and individual expression. Moreover, it is an ethical endeavour and it may enhance employee retention in organizations.

Following the "a complaint is a gift" inexpensive, abiding form of enforcement of law, rules and ethics in organizations or in society at large. Whistleblowing laws and policies acknowledge that wrongdoing, particularly by persons in authority, is an inevitable reality. These laws and policies offer a risk control and governance system for early detection, identification and management of compliance problems. ${ }^{46}$ If laws and policies are being violated, it is important for organizations and stakeholders to be the first to know that, in order for corrective action to be taken.

\footnotetext{
35 Ibid, s. 486.5.

36 Ibid, s. 486.

${ }^{37}$ Ibid, s. 486.2(2).

${ }^{38}$ Ibid, s. 486.2 (1).

${ }^{39} \mathrm{Ibid}$, ss. 486.3 and 486.4.

40 Ibid, s. 139.

41 Ibid, s. 423.1

42 S.C. 1996 , c. 15

${ }^{43}$ Ibid, ss. 4 and 5. See also, Gregory Lacko, 'The Protection of Witnesses' (November 2004, Department of Justice Canada), at http://www.justice.gc.ca/eng/pi/icg-gci/pw-pt/page4.html

44 See, generally, Wim Vandekerckhove, Whistleblowing and Organizational Social Responsibility, supra note []

45 Phrase borrowed from the book bearing that name by Janelle Barlow and Chris Moller, $2^{\text {nd }}$ ed (San Francisco, CA: Berrett Koehler, 2008)

46 Whistleblowing policy makers and administrators acknowledge many issues and concerns with whistleblowing regimes. These include impact upon morale, how to handle the chronic, obnoxious, bad faith or frivolous whistleblower, designation of whom is to receive the reports, effective investigations, etc.
} 
Ultimately, regardless of the venue, we all benefit from this enhanced level of law enforcement, accountability and justice.

\section{(c) Encouraging Whistleblowing}

Given that whistleblowing has inherent private and social utility, why is it so fraught with complications and resistance? Why do most workers who observe wrongdoing not report it? ${ }^{47}$ The standard response is fear of retaliation of some kind. Legislation relating to whistleblowing, to the extent it exists, is by nature law that prohibits retaliation against whistleblowers in stipulated conditions.

In the workplace alone, retaliation can come in essentially unlimited forms and degrees. Social shunning and ostracism, unfavourable discretion in earned performance appraisals, salary increases, promotions, desirable work and opportunities, bonuses, and perquisites are common forms of retaliation. More subtly, employees may be marginalized by restriction of information, consultation and decision-making ability. The greater the discretion held by the employer to reward and punish employees, the greater is the opportunity for workplace retaliation. In sum, employers (and it should not be overlooked, co-workers) can, intentionally or unconsciously, make life at work difficult for the whistleblower. ${ }^{48}$ Whistleblowers may be explicitly disciplined for expressing their concerns, even where corporate policy obliges one to do so and the whistleblower acts under a sense of legal obligation. Yet, retaliation may be much more subtle and difficult to detect. ${ }^{49}$ Thus,

\footnotetext{
${ }^{47}$ Marcia P. Miceli and Janet P. Near, "When do Observers of Organizational Wrongdoing Step Up? Recent US Research on the Factors Associated with Whistleblowing," in David B. Lewis (ed.), A Global Approach to Public Interest Disclosure: What Can We Learn From Existing Whistleblowing Legislation and Research? (Cheltenham, UK: Edward Elgar Publishing, Inc., 2010) at 79-80.

48 Peter Bowal, "Whistleblowers: All Truth is Good, But Not all Truth is Good to Say" (2003) 27:6 LawNow 32 ${ }^{49}$ See, Wojciech W. Gasparski, "Whistleblowing in the Light of the Praxiological Theory of Struggle," in Marek Arszulowicz and Wojciech W. Gasparski (eds), Whistleblowing: In Defence of Proper Action (New Brunswick, NJ:
} 
there is often a need to create whistleblowing incentives. Three models exist: mandate, tolerate, and compensate. ${ }^{50}$

Mandate: Workplaces may adopt a whistleblowing policy as part of a corporate governance or integrity program binding upon employees. Canadian legislation may require private actors to self-report violations of regulations. ${ }^{51}$ Whistleblowing may be mandated activity pursuant to professional Codes of Conduct. ${ }^{52}$ Teachers, child welfare workers, physicians and other professionals are bound by reporting mandates in the law because of the public interest positions they hold and the opportunity to observe harm and prevent further harm. As such, they are compelled to report wrongdoing on the part of both third parties and professional colleagues. ${ }^{53}$ These forms of compelled speech can give rise to constitutional free expression concerns..$^{54}$

Many corporate whistleblowing policies and Codes of Conduct state that employees have a duty not only to follow the procedure prescribed by the policy in making a report, ${ }^{55}$

Transaction Publishers, 2011) at 9, and Stephen M. Kohn, Concepts and Procedures in Whistleblower Law (Westport, Connecticut: Quorum, 2001) at 241-247.

${ }^{50}$ Peter Bowal, "Three Models of Whistleblowing Regulation," 85 th Annual Conference of the Academy of Legal Studies in Business, Richmond, VA, August 3-7, 2010 (unpublished conference paper). A fourth model, namely "litigate," applies informally where no specific legal coverage for whistleblowing can be found.

51 Mandatory self-reporting of "incidents" may not involve wrongdoing. It provides an early warning system for government regulators to investigate. Environmental legislation typically imposes this type of mandatory self-reporting for discharges of toxic substances. See, for example, Canadian Environmental Protection Act, 1999 (S.C. 1999, c. 33), s. 95.

The most recent federal example is the Canada Consumer Product Safety Act, S.C. 2010, c. 21. Effective June 20, 2011, businesses must report to Health Canada all health and safety incidents caused by their consumer products. Section 14(2) reads: "A person who manufactures, imports or sells a consumer product for commercial purposes shall provide the Minister and, if applicable, the person from whom they received the consumer product with all the information in their control regarding any incident related to the product within two days after the day on which they become aware of the incident."

52 The Law Society of Upper Canada's Rules of Professional Conduct are typical. Rule 6.01 on 'Responsibility to the Profession Generally' subs. (3) to (8) contain duties of lawyer members to report misconduct, certain offences,

and to encourage clients to report dishonest conduct. See http://www.lsuc.on.ca/with.aspx?id=671.

53 Peter Bowal and Ben Lau, "Professional Ethics" (2005) 29:4 LawNow 18.

54 Peter Bowal, "Reconciling Free Speech and Mandated Reporting of Wrongdoing by Professionals," 85 th Annual Conference of the Academy of Legal Studies in Business, Richmond, VA, August 3-7, 2010

(unpublished conference paper).

${ }^{55}$ It has been shown that employees who blow the whistle externally to regulators or the media may suffer harsher discipline than those who report internally in conformity to organizational whistleblowing policies. 
but they are under a legal duty, ostensibly sanctionable by discipline, to make the report of wrongdoing itself. ${ }^{56}$ Some employees who blow the whistle in accordance with these internal management policies nevertheless may themselves face retaliation for doing so because the internal disclosure policy is viewed by management more as a public value, and less as an intended practice. ${ }^{57}$ The policies themselves are usually written in mandatory language ("one must report ...”) but they are not mandatory in fact. In reality, publication of such policies becomes the "public" aspect, but very little is done beyond that - enforcement of the policies and investigations of reports often do not occur.

These mandatory obligations on individual whistleblowers to report wrongdoing must not be confused with the legal mandate upon organizations to implement a whistleblowing management system. In fact, while the former are becoming more common, only one instance of the latter mandate exists in Canada. Pursuant to the effect of the SarbanesOxley $^{58}$ exportation of American whistleblowing principles, the audit committee of the Board of Directors of all Canadian corporations registered on a United States stock exchange must establish an internal reporting system with "procedures for the receipt, retention, and treatment of complaints regarding accounting, internal accounting controls, or auditing matters and for the anonymous submission by employees of concerns on such matters. ${ }^{59}$ This internal, up-the-ladder reporting system, ${ }^{60}$ must be published across the

See, Peter Bowal, Thomas D. Brierton and Carlee Campbell, "The Whistleblower Defence to Employment Dismissal" (2007) 32:2 LawNow 35.

${ }^{56}$ We have found that "duty to report" clauses in professional Codes and corporate workplace policies are usually unaccompanied by sanctions for failure to comply with this duty to report. We have not been able to locate a single reported enforcement proceeding in the administrative regulation of professions against a professional who was aware of and failed to report a colleague's breach of the Code.

${ }^{57}$ A defence along the lines of "I was just doing my job" may be successful against termination but ineffective against other more subtle forms of retaliation.

58 The Public Company Accounting Reform and Investor Protection Act, 18 U.S.C. \$S 1514 (A)(a) (2002)

59 Ibid, Section 301

60 Most companies contract out compliance to "hotline" service providers. 
organization. Most provinces have informally agreed ${ }^{61}$ on duplicating this requirement to protect investors in companies listed on Canadian stock exchanges, enforced by participating provincial securities commissions, in what has become known as C-SOX. ${ }^{62}$

Tolerate: A model of toleration, by far the largest and widest-ranging form of control over whistleblowing, is found primarily in the regulatory domain. The idea behind this form of legislation is that individuals who volunteer reporting of regulatory offences, refuse employer orders to break the law, co-operate with investigations and give employer-adverse testimony in court should be protected. Thus, numerous regulatory statutes facilitate citizen reporting of offences by offering confidentiality assurances if requested by the whistleblower. In addition, retaliation in any form against the whistleblower, in these regimes, is considered a sanctionable regulatory offence. ${ }^{63}$ Compared to mandatory forms, however, legislation based on toleration does not compel reporting, nor does it reward it. But in order for protection to attach, an employee must comply with the qualifying criteria of the legislation, which may not be well known.

Section 16 of the Canadian Environmental Protection $A c t^{64}$ is representative of this type of regulatory protection. The Criminal $\operatorname{Code}{ }^{65}$ supplements this as a form of criminal restraint. The Code criminalizes supervisor and employer-organizational retaliation against whistleblowing employees who report the violation of any federal or provincial legislation to law enforcement authorities. ${ }^{66}$ This legislative reform was enacted in 2005 as part of the

61 In Ontario, this agreement has been incorporated into legislation in late 2002: Bill 198 amended the Ontario Securities Act, R.S.O. 1990, c. S.5, Part XXIII.1. See, H. Garfield Emerson, Q.C. and Geoff A. Clarke. "Bill 198 and Ontario's Securities Act: Giving Investors and the OSC Added Muscle." Paper presented at the 3rd Annual Directors' Governance Summit. November 17-19, 2003.

62 This informal convention among provinces is known by the name, Multilateral Instrument 52-110.

63 Whistleblower-tolerant legislation may also prescribe in detail internal up-the-ladder procedures for raising compliance concerns. See, eg., Canada Labour Code, R.S.C. 1985, c. L-2, s. 127.1.

64 S.C. 1999 , c. 33.

65 R.S.C., 1985, c. C-46.

66 Section 425.1. 
Canadian response ${ }^{67}$ to the Sarbanes-Oxley reform legislation to strengthen oversight, governance and accountability arising from large-scale corporate failures at the turn of this century. ${ }^{68}$ Although its intent is laudable, given its complexity ${ }^{69}$ and its requirement of proof of full mens rea, in our view it is unlikely that any convictions will result from it. ${ }^{70}$

Compensate: Under this category, whistleblowing is neither mandated nor merely tolerated. Instead, whistleblowing that qualifies - either under organizational policy or law is rewarded, either financially or in some other way. Providing tangible rewards recognizes the importance of detecting and correcting wrongdoing, the palpable risks taken in coming forward and the suffering that may accrue due to reprisals. The compensatory approach, while rare, offers some examples in practice.

The most prominent whistleblower compensation framework is the United States False Claims Act. ${ }^{71}$ The qui tam ${ }^{72}$ provision permits private individuals to sue on behalf of the United States to recover government losses due to fraud. ${ }^{73}$ If successful, the individual becomes entitled to a portion of the proceeds. ${ }^{74}$ More recently, the 2010 Dodd-Frank Wall Street Reform and Consumer Protection $\mathrm{Act}^{75}$ allowed compensation to whistleblowers in the financial sector. Subtitle B, headed "Increasing Regulatory Enforcement and Remedies,"

67 The Canadian response is an almost exact duplication of the Sarbanes-Oxley reforms in the U.S.: see Sukanya Pillay, 'Forcing Canada's Hand - The Effect of the Sarbanes-Oxley Act on Canadian Corporate Governance Reform,' (2003-2004) 30 Man. L.J. 285.

68 The Public Company Accounting Reform and Investor Protection Act, 18 U.S.C. $\iint 1514$ (A)(a) (2002)

69 Section 425.1 must be seen conjunctively with s. 140 (false accusation as public mischief) and s. 181 (spreading false news).

70 Peter Bowal, "Criminal Retaliation by Employers," Annual Conference of the Administrative Sciences Association of Canada, Banff, Alberta, June 6, 2006 (conference presentation).

7131 U.S.C. SS 3729-3733.

72 The full Latin phrase is qui tam pro domino rege quam pro se ipso in hac parte sequitur (who pursues this action on our Lord the King's behalf as well as his own).

73 See, Stephen M. Kohn, supra, note 8 at pp. 203 et seq.

74 Lamers v. City of Green Bay, 998 F. Supp. 971, 977 (E.D. Wis. 1998), affm'd 168 F.3d 1013 (1999).

75 H.R. 4173, \901. More specifically, the relevant provisions are in Title IX, sections 901 to 991, comprising the Investor Protection and Securities Reform Act of 2010. 
equips the Securities Exchange Commission (SEC) with expanded enforcement powers. ${ }^{76}$ These include an imprudently-named "whistleblower bounty program" whereby individuals who bring information leading to a successful SEC enforcement may receive between 10\% and $30 \%$ of the monetary sanctions over $\$ 1$ million. Canadian companies listed on a US stock exchange are governed by this law. ${ }^{77}$

There is no Canadian equivalent to the US False Claims Act. The original draft of the Public Servants Disclosure Protection Act ${ }^{78}$ proposed a cash reward for effective reports of federal public sector wrongdoing of up to $\$ 10,000 .^{79}$

The only whistleblower compensation program in Canada is operated by Crimestoppers, ${ }^{80}$ a national civilian, non-profit, charitable organization that works with community police services, the media and local community to combat crime. Cash rewards of up to $\$ 2000$ are paid to anonymous tipsters for information that leads to arrest of criminals, the recovery of stolen property or the seizure of illegal drugs. The organization's cumulative statistics on closure of crimes Canada-wide are impressive. As of March 2011, total cumulative value recovered from drug and property crimes was about $\$ 3.4$ billion. ${ }^{81}$

Whistleblowers' motives are frequently questioned and impugned in the ordinary course of mandatory and toleration whistleblowing. The 'bounty' debate about whether to

\footnotetext{
76 The Securities Exchange Act of 1934 (15 U.S.C. ch.2B).

77 This bounty concept, unfamiliar to Canadian business, is generally criticized: see Drew Hasselback, 'Whistleblower Bounty Plan Widely Assailed,' Financial Post (15 December 2010) FP12. The Dodd-Frank initiative, grounded in enhanced regulatory enforcement, is based upon a similar Internal Revenue Service (IRS) program from 2006. In that program, the IRS rewards whistleblowers who provide credible, original, specific information that any taxpayer has not paid the due taxes. If the tip leads to the recovery of over $\$ 2$ million in taxes and penalties, the tipster is entitled to between $15 \%$ and $30 \%$ of that amount, without maximum. Reports of smaller tax frauds are rewarded by up to $15 \%$ of the amount recovered - see United States Government, Internal Revenue Code, Title 26.

78 S.C. 2005 , c. 46.

79 As a remedial measure, the original draft amendments would have authorized the Public Servants Disclosure Protection Tribunal to "compensate the complainant, by an amount of not more than $\$ 10,000$, for any pain and suffering that the complainant experienced as a result of the reprisal." See, Bill C-2, 1stSession, 39th

Parliament, 55 Elizabeth II, 2006, s. 27.1 (1)(f).

80 http://www.canadiancrimestoppers.org.

81 Statistics shown here are as of 28 February 2011, from the Crimestoppers website, ibid.
} 
appropriately compensate legitimate disclosures to public authorities, and the distortions this approach may create, continues. ${ }^{82}$ On one hand, the compensation may attempt to match, if only symbolically, the risk and reprisal suffered by whistleblowers. If legitimate reporting is to occur, a financial inducement, however modest, may vindicate the whistleblower. On the other hand, the countervailing concern is that the promise of whistleblower compensation sets up a clear moral hazard. A policy to generate reports of wrongdoing, at least in part, by financially enriching the whistleblower, creates a risk that reports will be exaggerated or unfounded because the promise of compensation overwhelms and governs one's motives. Where the consequences of embellishment pale in comparison to the chance of reward mischief is the likely outcome. Despite the good intentions of a policy of compensating legitimate whistleblowers, anything in the order of windfall compensation, which is what may be required for full indemnity, is expected to generate more specious reports that consume investigative resources and goodwill than factually reliable reports. ${ }^{83}$

Regardless of the increasing prevalence of legislative initiatives, protection for whistleblowers also exists at common law.

\section{(d) Common Law: Employee Loyalty and Organizational Security}

Whistleblowing must be balanced against the common law implied duties of loyalty, fidelity and good faith to organizations, such as duties owed to employers and their

\footnotetext{
82 See, for example, Edward Waitzer, ‘Should We Pay for Whistle-Blowing?’ Financial Post (22 March 2011) FP11, and (responding) Dimitri Lascaris, 'Speak Truth to Power' Financial Post (25 March 2011) FP11

83 There are many instances of this mischief described, which creates a new level of organizational discipline. In a recent case in Calgary, Alberta, a long time drug addict reported to police that four men had killed one wild horse. The men were charged with criminal offences, lost their jobs, and endured substantial debts to pay for defence counsel. Two years later, the charges were dropped when evidence showed the horse died accidentally. It appears that the tipster was motivated to file a false report by the $\$ 25,000$ reward which had been offered by the Wild Horses Society. See Daryl Slade, "Charges Dropped Against Three Men in Sundre Wild Horse Shooting Case," Calgary Herald, April 27, 2011, at http://www.calgaryherald.com/Charges +dropped+against +three+Sundre+wild+horse+shooting + case/46835 72/story.html\#ixzz1KsM9AThX.
} 
security, ${ }^{84}$ and confidentiality interests. ${ }^{85}$ Generally, even non-fiduciary employees are under a duty to refrain from deliberately acting in a way that may harm the employer's business. ${ }^{86}$ Competing against one's employer, taking secret profits, setting up conflicts of interest, and divulging trade secrets or other confidential information have historically been the essence of this legal duty. ${ }^{87}$ Most or all of these latter activities are motivated, if not accompanied, by the employee's personal enrichment.

The same cannot be said of conscience-driven whistleblowing activity. Individuals choosing to disclose unlawful or harmful activity are unlikely to be enriched by it. A person's conscience may motivate him to action which is not always seen by others to be in his best interests. This is what makes the complexity of conscience-driven whistleblowing so fascinating.

Motives are relevant in the determination of which whistleblowers to protect from retaliation, and most laws and policies call for good faith disclosures. ${ }^{88}$ The motives of the whistleblower are usually grounded in the public interest, law enforcement and justice. It is not surprising, therefore, that Canadian courts and labour arbitrators have been willing to substantially narrow the common law application of the broadly-conceived employee's duty of loyalty and fidelity to good faith internal disclosures of actual or perceived wrongdoing. J.

84 Thomson v. Canada, [1992] 1 S.C.R. 385, 1992 CanLII 121; 89 D.L.R. (4th) 218; 3 Admin. L.R. (2d) 242; 51 F.T.R. 267, with respect to the public sector in relation to granting security clearances, at 396 (S.C.R.), per Cory, J.: “. . . all governments must maintain some degree of security and confidentiality in order to function. The most open democracy still requires a high degree of security and confidentiality with regard to many matters ... The degree of security required will vary with the position and role of the government employee. The higher the position, the greater will be the access to sensitive information, and the greater the need for security." 85 Stenhouse v. Canada (Attorney General) [2004] F.C.J. No. 469, (2004) 12 Admin. L.R. (4th) 299, (2004) 248 F.T.R. 248.

86 See generally, Stacey Reginald Ball, Canadian Employment Law (Aurora, ON: Canada Law Book, looseleaf), ch. 15.

87 Geoffrey England, Innis Christie and Merran Christie, Employment Law in Canada (Toronto, ON: Butterworths, looseleaf) at $\$ 11.113$ to $\$ 11.118$.

88 The definition of "protected disclosure" in legislation is often "a disclosure made in good faith ..." See, Public Servants Disclosure Protection Act, supra note 10, s. 2(1) and the Public Interest Disclosure (Whistleblower Protection) Act, supra note 11 , s. 2. 
M. Weiler, more than a quarter of a century ago, in his arbitral award in Re Ministry of Attorney-General, Corrections Branch and British Columbia Government Employees' Union declared: ${ }^{89}$

The duty of fidelity does not mean that the Daniel Ellsbergs and Karen Silkwoods of the world must remain silent when they discover wrongdoing occurring at their place of employment. Neither the public nor the employer's long-term best interests are served if these employees, from fear of losing their jobs, are so intimidated that they do not bring information about wrongdoing at their place of employment to the attention of those who can correct such wrongdoing. However, the duty of fidelity does require the employee to exhaust internal "whistle-blowing" mechanisms before "going public". These internal mechanisms are designed to ensure that the employer's reputation is not damaged by unwarranted attacks based on inaccurate information. Internal investigation provides a sound method of applying the expertise and experience of many individuals to all problems that may only concern one employee..$^{90}$

Reasonable and proportionate criticism of an employer's policies is also not likely to be viewed as a breach of fidelity. ${ }^{91}$ This "whistleblower exception" to the duty of loyalty was first acknowledged in 2001. ${ }^{92}$ In 2005, the Supreme Court of Canada in Merk v. International Association of Bridge, Structural, Ornamental and Reinforcing Ironworkers, Local $771^{93}$ strongly affirmed interpreting legislation to favour whistleblower protection. ${ }^{94}$ At issue in that case was whether Merk, who reported financial regularities to her union leadership - not a public body - had reported to a "lawful authority" in accordance with the Saskatchewan Labour Standards Act whistleblower-protective provisions. Binnie J. stated: ${ }^{95}$

...Linda Merk's letter to the General President of the International Union of Iron Workers that "blew the whistle" on these alleged financial abuses was a complaint "to a lawful authority" within the meaning of the Act and brought Merk within the Act's protection. The plain meaning of "lawful authority" includes those who exercise authority in both the private

\footnotetext{
89 (1981), 3 L.A.C. (3d) 140 at 163.

90 Cited with approval by Binnie, J. in Merk v. International Association of Bridge, Structural, Ornamental and Reinforcing Iron Workers, Local 771, [2005] 3 S.C.R. 425, 260 D.L.R. (4th) 385, [2006] 5 W.W.R. 114, 2005 SCC 70, 47 C.C.E.L. (3d) 1, 275 Sask. R. 1 [Emphasis added by SCC].

91 Alberta Union of Provincial Employees v. Alberta, supra note 18; Fraser v. P.S.S.R.B., supra note 19.

92 Haydon v. Canada, [2001] 2 F.C. 82 (TD).

93 [2005] 3 SCR 425, 260 DLR (4th) 385, [2006] 5 WWR 114, 47 CCEL (3d) 1, 275 Sask R 1, 2005 SCC 70 ("Merk").

${ }^{94}$ See Barbara B. Johnston, Birch K. Miller and Gary T. Clarke, 'On the Horizon: Increased Protection for Whistleblowers,' (Mar. 2006) 15 Can. Corp. Counsel 69-70; Peter Bowal, "Wrongdoing at Work: Who 'Ya Gonna Call?” (2006) 30:4 LawNow 13; Sean C. Doyle, 'A Purposive Approach to Whistleblower Protection, (2007) 44 Alta. L. Rev. 903-910.

95 Supra, note 93 at para 3.
} 
and public context. If the legislature had wished to limit the scope of s. 74 to complaints to a "public authority", it would have said so. The correctness of the broader interpretation is reinforced by the purpose and context of [the Act], as will be seen. Based on the trial judge's findings of fact, the union's dismissal of Merk violated the Act.

His Lordship continued: ${ }^{96}$

Whistleblower laws create an exception to the usual duty of loyalty owed by employees to their employer. When applied in government, of course, the purpose is to avoid the waste of public funds or other abuse of state-conferred privileges or authority. In relation to the private sector (as here), the purpose still has a public interest focus because it aims to prevent wrongdoing "that is or is likely to result in an offence". (It is the "offence" requirement that gives the whistleblower law a public aspect and filters out more general workplace complaints.) The underlying idea is to recruit employees to assist the state in the suppression of unlawful conduct. This is done by providing employees with a measure of immunity against employer retaliation. " $[\mathrm{R}]$ eports from insiders allow for early detection and reduction of harm, reduce the necessity for and expense of public oversight and investigation, and may ultimately deter malfeasance" 97

The Merk case arose a few months after Vaughan v. Canada, ${ }^{98}$ in which Justice Binnie, again for the majority, acknowledged the presence of an exceptional category - referred to as "the Whistle-Blower Cases" $" 99$ - which allows courts to employ their residual jurisdiction to hear whistleblowing cases where the inherent impartiality or potential conflicts may render the normal grievance process inappropriate. The Court thus circumvented the stringent $W e b e r^{100}$ line of authorities in labour relations. ${ }^{101}$ Although technically the Court relied on a statutory provision ("lawful authority"), Binnie J.'s holding went far beyond what was necessary, seemingly bending over backwards to find support for whistleblowers. Thus, it seems more proper to cast this as a common law principle - which again, we feel could be derived from conscience.

\footnotetext{
96 Supra, note 93 at para 14

97 Citing E. S. Callahan, T. M. Dworkin and D. Lewis "Whistleblowing: Australian, U.K., and U.S. Approaches to Disclosure in the Public Interest” (2004), 44 Va. J. Int'l L. 879, at p. 882.

98 [2005] 1 S.C.R. 146, 2005 SCC 11.

99 Ibid at paras 18 to 24.

100 Weber v. Ontario Hydro, [1995] 2 S.C.R. 929.

101 New Brunswick v. O'Leary, [1995] 2 S.C.R. 967; Brotherhood of Maintenance of Way Employees Canadian Pacific System Federation v. Canadian Pacific Ltd., [1996] 2 S.C.R. 495; Regina Police Assn. Inc. v. Regina Board of Police Commissioners, [2000] 1 S.C.R. 360; Allan v. Alberta, [2003] 1 S.C.R. 128, 2003 SCC 13; Goudie v. Ottawa, [2003] 1 S.C.R. 141, 2003 SCC 14; Bisaillon v. Concordia University, 2006 SCC 19; Isidore Garon ltée v. Tremblay, [2006] 1 S.C.R. 27.
} 
In the final analysis, the Supreme Court of Canada has, in its approach to both statutory interpretation and the common law in the context of whistleblowing, been supportive of an expansive approach to recognizing legal protections for whistleblowers. However, we think that a potentially more effective approach could be to recognize whistleblowing as an activity deserving of constitutional protection as a matter of freedom of conscience. In order to do this, we first make the argument that freedom of conscience deserves independent status, before showing how it would apply in the context of whistleblowing.

\section{Conscience: A Constitutionally Protected Freedom}

Section 2(a) of the Charter states that everyone has freedom of conscience and religion. Undoubtedly, religion and conscience have much in common both historically and theoretically. But in a legal, constitutional sense they should be treated separately. Freedom of conscience can function as a fully realized, independent freedom, since its meaning is sufficiently distinct from "religion."

The English word "conscience" comes from the Latin term conscientia, which means knowledge within oneself, or self-knowledge. It connotes a joining of knowledge of things to self-knowledge. Conscientia first appeared in the New Testament: in particular, through the writings of the apostle Paul. In his Epistle to the Romans, for example, he noted: "wherefore [ye] must needs be subject, not only for wrath but for conscience’s sake.”102 Originally, conscience represented a joining of an individual's judgment to God's knowledge of right and wrong, and a joining of self-knowledge to God's knowledge of our thoughts and

102 New Testament, Romans 13:5. (King James translation). 
intentions. ${ }^{103}$ Obeying one's rulers and authority figures was thought good not just because of the fear of civil punishment associated with disobedience, but was a way to do good, through a conscience that accorded to God's. Its English origins are thus tied strongly with Christian thought; in fact, there are no Sanskrit, Chinese or Japanese words for conscience. ${ }^{104}$ According to the Oxford English Dictionary, the first English use of the word "conscience" occurred in 1225, where it was used in the moral sense of a "consciousness of right and wrong", or as the "deity within us." 105 Originally, it referred to the whole moral nature of humankind, but it gradually became personified and individualized. Further refinements followed: the OED gives Shakespeare's example from Hamlet, in which Hamlet laments that "conscience does make Cowards of us all,"106 which, on one reading, suggests a doubting kind of conscience or the conscience that keeps us from acting as our true selves (acts, by implication, that would get us into trouble). Conscience is also used to describe an inward knowledge or consciousness, such as an internal conviction. Although both meanings derive from the self-knowledge of conscientiaa, the English word implies a moral standard of action in the mind as well as a consciousness of our actions. Conscience is thus the application of reason, employed about questions of right and wrong, and accompanied by sentiments of approval or condemnation. ${ }^{107} \mathrm{~A}$ second, related, meaning refers to a conscientious observance or practice; the sense of a practice of, or conformity to, what is right. This meaning is commonly invoked in cases of conscientious objectors. Again, Shakespeare employs it in all these ways, sometimes meaning moral judgment, other times religious scruples and sometimes as inward reflection.

103 See William Perkins, The Whole Treatise of the Cases of Conscience, Distinguished Into Three Books (originally published in 1606 -- published under The English Experience: Its Record in Early Printed Books Published in Facsimile, Amsterdam: Thetrvm Orbis Terrarvm, 1972).

104 See Edward G. Andrew, Conscience and Its Critics (Toronto: University of Toronto Press, 2001) at chap. 1.

105 See Oxford English Dictionary online, (Oxford University Press, 2009). (“OED”).

106 William Shakespeare, Hamlet, Act III, 1. ( 1600).

107 See Webster's Revised Unabridged Dictionary, 1996. 
"Conscience" is often invoked as a negative, in the sense of "having something on one's conscience," or less euphemistically tied to wrongdoing, as a "guilty conscience," having to "clear one's conscience" or acting in a "fit of conscience" "108 from an existing guilty thought or deed (as Kant says, "Prudence reproaches, conscience accuses"). ${ }^{109}$ It can also represent an institutional or individual seal of trust or authority: "the conscience of the court" or "binding on one's conscience," which can, at its limits, be offended or astounded, as in situations that "shock the conscience."

As Wilhelm Mensching aptly describes it, conscience is the human "inner ear" for the voice which tells us what we should do and what we should leave undone, what the pattern and purpose of our lives should be. But it is more than the existence of this voice -it is the particular human ability to hear this voice within. Conscience thus acts as a warning mechanism, telling us that certain work, thoughts, feelings or acts, are wrong-headed or evil; at other times conscience acts as a calling, urging and impelling action, words, thoughts or feelings as being right and dutiful. ${ }^{110}$ All adult humans have this conscience within. As Paul noted, in his letter to the Romans, even "heathens" have a conscience: they have the moral law "written in their hearts, their conscience also bearing witness, and their thoughts the [mean] while accusing or else excusing one another." "111 The modern-day recognition of this fact is found in the first Article of the U.N. Declaration of Rights, which reminds us that "all human beings $\ldots$ are endowed with $\ldots$ conscience ..."112

\footnotetext{
108 Chatterjee v. Ontario (Attorney General), [2009] 1 S.C.R. 624 at para 46.

${ }^{109}$ Immanuel Kant, Lectures On Ethics, (Cambridge: Cambridge University Press, 1997) 24.

110 Wilhelm Mensching, Conscience, (Wallingford, Pennsylvania: Pendle Hill Pamphlets, 1961) (translated by Ian Hagerty and Caroline Nicholson Jacob).

111 New Testament, Romans 2:15 (King James translation).

112 Universal Declaration of Human Rights, Article 1 (UDHR).
} 
The metaphor of a voice within (particularly the "voice of God") is what brings conscience naturally inside the religious sphere. ${ }^{113}$ For centuries, conscience had an almost material quality, interposed between God and Man:

Man hath two witneffes of his thoughtes, God, and his owne confcience; God is the firft and chiefeft; and Confcience is the fecund fubordinate vnto God, bearing witness vnto God either with the man or againft him... The naturall condition or propertie of euery mans confcience is this; that in regard of authoritie and power, it is placed in the middle betweene man and God, fo as it is vnder God and yet aboue man. And this naturall condition hath two parts: the firft is the Subiection of consfcience to God and his word.114

Socrates, Jesus, Luther and Gandhi, for example, all referred to their conscience as the voice of God.

One's conscience is also mutable. For years, Luther maintained an attitude of respect and forbearance toward the Catholic church - his conscience brooked no opposition to it. It was only as he aged and developed his own thinking on religion that his attitude changed. Again, as with religious belief, conscience is not necessarily, to all people at all times, the infallible voice of truth, morality, or God. Our consciences can ignore things unintentionally and unknowingly, or intentionally and deliberately. Errors can be made where our own conscience confuses other external voices with the inner voice of truth, reason, humanity, or morals, etc. Since conscience cannot perceive all truths, understand all reason - or, for religious believers, be equivalent to God - it is also prone to error. It is constantly receiving other voices, such as those from parents, religious institutions, the state, and the broader culture and society surrounding us. These often substitute for conscience, taking over its autonomy and usurping its role:

\footnotetext{
113 Mahatma Gandhi spoke of conscience in this way: see Raghavan Iyer, The Moral and Political Thought of Mahatma Gandhi (New York: Galaxy Books, 1978) at 122: "I simply want to please my own conscience, which is God."

114 Perkins, supra note 103 at 44.
} 
Hence, very different decisions are made about what is true, right and moral. It is the environment, and not the voice for which we each possess a conscience, that determines the decisions of such consciences. ${ }^{115}$

Although these external voices may become internalized into one's conscience (and they should, in some cases, in order to allow a conscience to evolve) they can act both constructively and destructively on our consciences. Since we adults all have a conscience, however, it is in our view proper to say that those who commit acts of barbarism or are evil are not devoid of conscience but are acting against conscience. The mutability of conscience is, however, one of its strengths. A conscience true to its humanity cannot remain satisfied with the status quo: "we have been given a conscience so that we can hear a voice which wants more than strict observance of the rules valid in our community or in any other group."116 A healthy conscience continually changes to reflect a better understanding of the world around us.

Different religions and individual consciences manifest themselves in a nearly limitless variety of forms, often diametrically opposed to one another. The major religions, for example, have vastly different views on what might be the ultimate purpose or divine understanding of the universe. Even more mundane religious beliefs (or social customs that often are associated with religious practices) can lead in different directions: many Jews and Muslims do not eat pork while many Hindus do not eat beef; each of them relate these practices to religious dogma. We can see similar effects surrounding conscience-based beliefs: Martin Luther's conscience compelled him to attack the Catholic church while Thomas More's required him to defend it. Or, in a more modern vein, followers of Martin Luther King Jr. and his non-violent resistance to segregation were led by their consciences to believe that the laws were wrong and unjust; those in the South trying to uphold the laws

115 Mensching, supra note 110 at 13.

116 Ibid at 14. 
must have felt it in their conscience that the laws protected both whites and blacks alike. Conscientious objectors feel compelled to object to military service while others may have a conscientious belief that fighting and dying for one's country is the best path. As Mensching says, two people can arrive at opposite conclusions and yet both can be making a decision based on conscience. ${ }^{117}$

Conscience-based freedom could be used to protect a much broader segment of beliefs and practices. For one, a broad reading of freedom of conscience might protect those who are persecuted at the time for heresy, but in retrospect, are creating new religions. Martin Luther may have received little or no protection for his beliefs under a traditional notion of freedom of religion because, before his writings and the mounting of his 95 theses, Protestantism, as a religion, did not exist. If his freedom of conscience were protected, the result may have been different. Similarly, Joseph Smith (and later Brigham Young) may not have had to lead his adherents from New York to Utah to escape the long arm of the state. It is also clear, however, that conscience-based guarantees can go beyond any connection to religion. The ability to hear the voice of truth, humanity, reason or moral law is not dependent on membership in a religious community nor on a belief in God.

Although conscience normally pertains to individuals, it is important to recognize that some connotations of "conscience" reflect a wider constituency and call to action. Since our conscience can teach us what is right and wrong with others and society, and ask us to "do good" to both, it can reach beyond the individual, to a social conscience. The Preamble to the UDHR alludes to this wider understanding of conscience: "Whereas disregard and contempt for human rights have resulted in barbarous acts which have outraged the

117 Ibid at $10-11$. 
conscience of mankind..." ${ }^{\prime 18}$ Sometimes the awakening of a single conscience leads to the formation of a public conscience against what had not been previously recognized as an injustice or inhumanity. History is thus replete with examples where numbers of humans have been led by conscience to recognize and fight injustice, inhumanity and evil. Witness Mahatma Gandhi's acts of civil disobedience or Nelson Mandela's call to dismantle apartheid -- the expansion of their fight into the public conscience eventually galvanized support for change (of course, theirs were not the only voices, but their public display of conscience was an important factor in rousing public sentiment). Public conscience reflects a healthy consideration for the future. A conscience which does not want to know, for example, what will happen to the planet as a result of climate change and the consequences it will have for future generations, is unhealthy and limiting. ${ }^{119}$ To some extent, it is the "public conscience" that is reflected primarily in law: ${ }^{120}$ for example, the highest moral order as signified by the criminal law is said to be the "legislated conscience of the state." 221 Thomas Hobbes had the public view of conscience in mind in the Leviathan where he recalled that "conscience is a thousand witnesses" despite the effort of "men vehemently in love with their own opinions [giving them the] reverenced name of conscience." 122 In Hobbes' state of nature, where a person is "subject to no civil law" there is every chance that one will "sin in all he does against his conscience because he has no other rule to follow." ${ }^{\text {"23 }}$ In contrast, those who live in society have the "law [as] the public conscience by which [they have] already undertaken

\footnotetext{
118 Supra, note 112.

${ }^{119}$ See supra note 110 at 23. Mensching uses the example of nuclear testing and nuclear war to explore the importance of a collective conscience.

${ }^{120}$ See Stanley Fish's blog - NY Times, April 12, 2009: "Think Again: Conscience vs. Conscience" http:// fish.blogs.nytimes.com/2009/04/12/conscience-vs-conscience/.

121 R. v. Cyrenne (1981), 62 C.C.C. (2d) 238 (Ont. Dist. Ct.).

122 Thomas Hobbes, Leviathan, (Indianapolis: Bobbs -Merill Educational Publishing, 1978) at 63.

123 Ibid at 254.
} 
to be guided." 124 The great diversity of private consciences, which according to Hobbes are simply "private opinions" mean that without the public conscience of society and the law, there would be no need to obey the sovereign any more than one felt it necessary to do so. ${ }^{125}$ In sum, as a word carrying distinct meanings, "conscience" has a strong claim to be recognized as an independent freedom with separate constitutional status from religion. It needs to be treated as more than just a synonym or substitute for religion.

\section{Freedom of Conscience for Whistleblowers: An Approach to s. 2(a)}

A model for understanding and assessing freedom of conscience claims for whistleblowers is based on two key points: (i) that the claim has some connection to morality; and (ii) that the strongest claims evince some form of compulsion. In addition, our model protects against abuse; in other words, floodgate concerns are acknowledged and addressed.

\section{(a) Freedom of Conscience May Require Some Connection to Morality}

Liberalism takes the moral primacy of a person as one of its most important aspects. Each person is separate, with his or her own interests and aims, free and independent - the "unencumbered self." 127 At the heart of this individuality lie human conscience and its concomitant freedom. Individual conscience lets us act in a manner that is true to self.

\footnotetext{
124 Ibid.

125 Ibid.

126 While it is beyond the scope of this article, it is important to refer to the growing body of behavioural social science literature that attempts to identify the traits of whistleblowers and predict their actions. It is this emphasis on understanding human behaviour which leads us to consider the interplay between conscience and whistleblowing, both areas of the law which are just beginning to receive theoretical and jurisprudential development in Canada. 127 Michael Sandel, ed, Liberalism and its Critics (Oxford: Blackwell, 1984) at 4-5.
} 
Yet, if it is to have some deeper meaning - and traction, especially for purposes of legal constitutionality - freedom of conscience must be more than simply any act of a conscious or sentient mind. The need to have some moral component attached to an act is an obvious point of departure. It would seem to be difficult to imagine freedom of conscience used to backstop an argument that conscience required driving on the wrong side of the road (unless it was to avoid something alive in the way), or use a sledgehammer instead of a screwdriver to affix a hinge to a door. On the other hand, it is more plausible to accept the views of someone claiming to be a vegan because her conscience would not let her eat meat. We might even grant the same person some ground to argue that her conscience will not allow her to see other humans eat meat, although her demands upon others at this point call for deeper analysis.

In the same way that "religion" has been interpreted broadly for purposes of constitutional law, a generous interpretation of morality would make sense in the context of conscience as it appears in s. 2(a). Moral convictions and commitments could be those that result from a conscious effort to discern, hopefully after some consideration, what choices one makes about what is right rather than wrong, just rather than unjust, good rather than bad. ${ }^{128}$ For some, there is obviously a strong connection to religion in the choices that will be made. In this broad sense, individual subjective morality seems to belong within a conscience-based legal claim; whether it is necessary or simply sufficient and how far morality can affect others is less certain.

What makes the case of vegetarianism potentially different from the choice of which lane or tool to use, is, at least for the courts, the fact that some reasonably important moral component is engaged (albeit, subjectively). We see this in the limited jurisprudence on

128 See Michael Perry, "From Religious Freedom to Moral Freedom” (2010) 47 San Diego L. Rev. 993 at 996. 
freedom of conscience: courts have all interpreted "conscience" as belonging to a moral or ethical dimension. In Syndicat Northcrest v. Amselem, ${ }^{129} \mathrm{R} v$. Morgentaler ${ }^{130}$ and R. v. Big M Drug Mart, ${ }^{131}$ for example, the Supreme Court of Canada has referred to conscience as consisting of deeply held beliefs and practices that are akin to religious beliefs and practices. Chief Justice Dickson referred to the possibility of conscience as a secular parallel to religion, the latter simply a "prototypical" and "paradigmatic" system of belief and practice that might well be subsumed under the larger body of a conscience-based liberty. ${ }^{132}$ Justice Wilson in Morgentaler similarly articulated the freedom as belonging to some form of personal morality that exists outside religion, namely a "secular morality." 133 This ties conscience to religion, but at the same time recognizes its secular distinctiveness. It ensures conscience is tethered to its foundation in conscientiaa, and is not simply any decision made, or action taken, by a sentient being.

The difficulty with this articulation of the freedom is, as might be expected, determining the exact parameters of "morality." In Morgentaler, Wilson J. seems to treat morality as a matter of human agency or autonomy. It is the "woman's right to choose" she states, that must be constitutionally protected. ${ }^{134}$ Are there to be any limits placed on this choice? Or is the constitutionally protected choice to be grounded in morality, as is presumably the case in deciding whether or not to terminate a pregnancy, but then autonomy kicks in and allows individual choice to govern? In other words, is Justice Wilson

129 [2004] 2 S.C.R. 551 (Amselem).

130 [1988] 1 S.C.R. 30 (Morgentaler).

131 [1985] 1 S.C.R. 295 (Big M Drug Mart).

132 Ibid at para 123. Of course, this observation is itself problematic. There can be deeply religious commitments about how to wash one's hands before a meal, for example. The moral status of these practices is said to come from God; without which they could begin to look like which side of the road one should drive on. We attempt to deal with this by adding the qualifier "reasonably important" or "deeply" to indicate moral beliefs of some profundity.

133 Wilson J. in Morgentaler, supra note 130 at 179, quoting Professor Cyril Joad in Guide to the Philosophy of Morals and Politics.

134 Ibid, Morgentaler at 147. 
advocating for a threshold decision based on morality in order to invoke freedom of conscience? This has a superficial attraction to it, but can also lead to confusion: washing hands before eating or prayer, for some religious adherents, is a matter of morality because it stems from a command from God. On the other hand, one can easily imagine decisions to terminate a pregnancy not based on morality - because having a child would, for example “cramp my single lifestyle," or would add to the "four children I already have and I don't need any more".) A person's right to choose can all too easily become any decision made consciously. So the right to choose may not relate to morality, nor does the significance or insignificance of an act necessarily point us toward its morality.

The only case in Canada in which a court relied solely on freedom of conscience to ground its decision is Maurice v. Canada (A.G). ${ }^{135}$ In that case, Campbell J. allowed Jack Maurice, a non-religious inmate at a federal prison, to receive vegetarian meals on the basis that his freedom of conscience was offended by a prison regulation permitting vegetarian meals for religious reasons but no others. Unfortunately, it is unclear in Campbell J.'s decision whether a moral element alone was sufficient to raise a claim of constitutionally protected freedom of conscience. His reasoning was ambiguous on this point - on one hand, it seemed as if some form of moral repugnancy or aversion was important (vegetarianism was based on the "immorality of eating meat") - but at the same time he noted that "motivation for practising vegetarianism may vary." 136 This is an important distinction. Vegetarians cite numerous reasons for avoiding eating animal products (or, in the case of vegans, using them in any way): the love of animals; the need to alleviate the willful suffering of a fellow sentient being; the health benefits of avoiding meat; the increased efficiency of a vegetarian diet; the negative environmental effects of raising livestock; the

135 [2002] FCT 69 (Maurice).

136 Ibid at para 10. 
more aesthetically pleasing look of vegetables compared to muscles, wings and fat. ${ }^{137}$ Would an independent freedom of conscience protect a person who relied on any one of these reasons? Alternatively, does it require someone to rely on only those reasons that can be considered moral? (Which might exclude the aesthetic reason for being a vegetarian?) Or does conscience require at a minimum, as Justice Campbell hinted, a connection to moral disgust? And since he shied away from invoking s. 15, it is unlikely that he relied on another potential moral ground: equality or fairness in treatment between inmates.

In sum, where conscience has been invoked as a legal freedom in Canada, it has usually required some connection to morality, although the content of that morality, and the extent of its connection, is unclear. The importance of morality will thus need to be considered in developing a conscience-based framework for adjudication.

\section{(b) Compellable Practice}

A claim that a belief or practice is based on conscience should exhibit qualities similar to those felt by adherents to religious doctrine: in many instances the practice, if avoidable at all, is only done so at great personal cost to the claimant. Thus, it is not the "still, small voice of conscience" that whispers to them, but a voice loud and insistent enough that compels some to suffer grave personal trauma, or even face incarceration, rather than fight against it. ${ }^{138}$ The prototypical examples are Thomas More and Mahatma Gandhi, whose unbending consciences - their "moral squint" - would not let them do the easy thing,

137 See, for example, Peter Singer, Animal Liberation (New York: Ecco, 2002).

138 See Welsh v. United States 398 U.S. 333 (1970). 
or the common sense thing, but instead cast their views against majority opinion of the day. $^{139}$

Constitutionally protected conscience-based acts may also require a certain deliberateness and intent. In our view, it would be difficult to conceive of an act of conscience that is instinctual, reactive or hot-blooded. A person claiming that his conscience made him dive into the water to rescue a drowning child would not be believed. Consciencebased decisions, at least those that might engage legal protections, are more likely to be those that require time to consider, such as the inner debate one would have over whether to become a vegetarian, have an abortion, object to war or opt for euthanasia. ${ }^{140}$ They seem to flow from an imperative, similar to religious-based actions that receive legal protection. Stated differently, these decisions stem from a sense of conviction about an act: it is not what one wants to do, or why one wishes to do it, but the fact of compulsion that makes conscience-based decisions worthy of comparison to religious ones.

Much of the jurisprudence on freedom of conscience refers to the importance of compulsion in assessing claims. In some cases the court casts it in the language of duty: in $R$. v. Videoflicks, ${ }^{141}$ Tarnopolsky J. spoke of the belief that "requires" a person to close his shop on a day other than a Sunday; in Maurice Justice Campbell notes how Jack Maurice continued to seek a vegetarian diet against strong opposition, recognizing his "sustained efforts to maintain a vegetarian diet" as an important factor. Although Campbell J. did not invoke the

${ }^{139}$ See Robert Bolt's play, “A Man For All Seasons” where Cardinal Wolsey says to More: “You're a constant regret to me, Thomas. If you could just see the facts flat on, without that horrible moral squint; with just a little common sense, you could have been a statesman.” (Samuel French: London) Act I, Scene 2, p. 21.

${ }^{140}$ Compare with Kristen Monroe, The Hand of Compassion: Portraits of Moral Choice During the Holocaust (Princeton: Princeton University Press, 2004). Monroe uncovers, in her interviews with people who rescued Jews from the Nazis, that many felt they had no choice, that their actions (which in many cases threatened their own lives) were not the result of deliberation. Does this not nevertheless involve the rescuer's conscience? I do not think my suggestion for some form of deliberation goes against her position - it seems to me that a truly instinctive reaction (diving into water) is different from "rescuing" someone from the Nazis, as the latter does not arise without warning or come completely by surprise. The time for deliberation may not be long in such cases, but it is still sufficient to engage one's conscience.

141 (1984) 48 O.R. (2d) 395. 
language of compulsion, it is clear in his decision that he understood the deeply-felt nature of Maurice's vegetarianism. Where compulsion is absent, courts have decided the opposite. For example, in finding that Charles Roach could not rely on freedom of conscience to obtain his citizenship without swearing allegiance to the Queen, MacGuigan J.A. for the majority pointed out that the Citizenship Act does not impose an oath of allegiance on an applicant. ${ }^{142}$ Similarly, where hunting advocates tried to rely on conscience as a basis to continue fox hunting, the court was unsympathetic to their plight, partially on the basis that nothing in the animal protection legislation "compelled" them to act contrary to their consciences. $^{143}$

None of the cases, however, makes it clear whether this is either a necessary or sufficient component of a constitutional conscience-based obligation. Nor is there consistency on whether the feeling of compulsion is derived subjectively - from the perspective of the individual claimant - or objectively.

Some courts question the necessity of compulsion. Although Campbell J. in Maurice discussed the nature of Maurice's desire to avoid eating animals, he seemed to be of two minds regarding a person's conscience-based motivation. He stated that vegetarianism is a “dietary choice." ${ }^{144}$ In Morgentaler, Justice Wilson observed that a person's right to choose is an inherent right flowing from the nature of conscience as a fundamental freedom. Although some women may feel a compulsion to obtain an abortion at all costs, it is more likely that women choose to have an abortion amongst a range of alternative options. What brings the decision within realm of conscience for her is that the option to choose an abortion is an exceedingly difficult choice to make. And while Wilson J. never discussed compulsion as an

\footnotetext{
142 Roach v. Canada (Minister of State for Multiculturalism and Culture) [1992] 2 F.C. 173 (Linden J. dissent not disagreeing with this point).

143 Whaley v. Lord Advocate [2004] SC 78 (Outer House) at para 74.

144 Maurice, supra note 135 at paras 15, 9.
} 
attribute of conscience-based decision-making, she acknowledged the intense personal conviction that would almost certainly accompany a woman deciding whether or not to procure an abortion. It is not a decision entertained lightly. It may involve family members, friends, religious advisors, doctors and other health officials. While perhaps not compelled, it is such a long way from another person's decision to, say, drive on the wrong side of the road or snort cocaine, that it could be said to be different in kind. ${ }^{145}$

Evn if compulsion is necessary, there remains the problem of subjectivity. In $R$. (Williamson) v. Secretary of State for Education and Skills, ${ }^{146}$ Lord Nicholls indirectly referred to the idea of conscience-based compulsion by recognizing that some beliefs carry with them "perceived obligations" to act in certain ways. ${ }^{147}$ But he set this up against other beliefs that may lack an obligatory element, without stating directly that legal freedom of conscience requires obligation nor whether it should be subjectively or objectively measured. In Roach, the claimants own feeling that the oath was compelled seemed to carry little weight. Given the range of views in all these cases, compellability will become a key factor in developing a framework for conscience-based whistleblowing analysis and will help address the possibility of bogus claims.

Indeed, some judgments have recognized the potential abuse of conscience-based claims. In Videoflicks, Tarnopolsky J. sought to rein in false claims by centering his analysis on the individual, but noting that one's conscience cannot be offended by others' actions or freedoms. He also sought to ensure that conscience-based freedoms are based on beliefs which are binding on, or at least strongly felt by, someone. Likewise, running throughout Madam Justice Wilson's opinion in Morgentaler is the notion that it is a deep and difficult

145 David Richards, Toleration and the Constitution (New York: Oxford University Press, 1986) at 75-77. 146 [2005] UKHL 15; 2 AC 246.

${ }_{147}$ R. (Williamson) v. Secretary of State for Education and Skills [2005] 2 AC 246; 2 All ER 1 (HL) at para 32. 
decision for any woman to choose whether to have an abortion, which butts directly up against - as it did in 1988 - the state's attempt to compel a woman to carry a foetus to term. For her, it is clear that a conscience-based decision must rest on a measure of profundity. The decision is an "important" one, "intimately affecting" one's private life, ${ }^{148}$ that will have "profound psychological, economic and social consequences" and which engender "powerful considerations militating in opposite directions""149 for a pregnant woman. Put bluntly, for Justices Wilson and Tarnopolsky, conscience-based decisions need to be fundamental decisions that go to the heart of what a person is, and what he or she believes in. While these factors remain attractive, it is worth noting that this standard may be set a little too high for whistleblowers, who usually turn to their sense of justice or truth or honour before revealing all.

Many judicial decisions require a conscience-based belief to be sincerely held, in the same way that the Supreme Court's test for religious freedom, developed in Amselem, requires a sincere, subjective belief. The need to have sincerity ground a conscience-based belief is equally strong - in fact, arguably it is even more important than in religious freedom cases since conscience-based beliefs, by definition, do not have the imprimatur of a religion to back them up. As such, we see decisions based on conscience which require a "deep and sincere belief," 150 a "genuine belief,"151 or where petitioners are "sincerely convinced" $" 152$ of their belief. One way of locking the floodgates from spurious claims of conscience, is to test the validity and legitimacy of a claim through the sincerity of the claimant. It is an affront to the freedom itself if those claiming freedom of conscience were doing so simply to escape

\footnotetext{
148 Morgentaler, supra note 130 at para 240.

149 Morgentaler, supra note 130 at para 241.

150 Welsh, supra note 138 at 340 .

151 Videoflicks, supra note 141 at para 45.

152 Whaley supra note 143 at para 74.
} 
performance of a legal obligation binding upon others. Even someone who may not be making a spurious claim, but who is doing so on the basis that it is a pragmatic option, should also be controlled. Sincerity aids in ensuring, as described by Laurence Tribe in the context of religion, that an overly broad approach to freedom of conscience would not become a "limitless excuse for avoiding all unwanted legal obligations."153

Moreover, sincerity is one aspect of a freedom of religion claim that courts are comfortable assessing. As the Supreme Court stated in Amselem, it is qualified to "inquire into the sincerity of a claimant's belief, where sincerity is in fact at issue," despite being unable or unqualified to rule on the validity of religious practices or beliefs. ${ }^{154}$ Courts are used to assessing witness sincerity and constitutional claimants are no exception. In a claim for freedom based on conscience, a court could examine, for example, whether the practice or belief reflects a pattern of behaviour that is consistent; whether there is some personal cost to the course of action taken by a claimant; whether the benefit received by avoiding a legal obligation is met by other costs that most people would not voluntarily incur. ${ }^{155}$

Campbell J. in Maurice recognized this when he struck a suitably cautionary note by requiring proof of "cogent evidence" for a conscientious belief claim. ${ }^{156}$ Cogent evidence means objective, external evidence. In the Maurice case a few factors led the Federal Court to accept the legitimacy of Maurice's conscience claim: his numerous requests and grievances, the extensive time and effort spent on judicial review and his sustained efforts, against institutional obstruction, to maintain a vegetarian diet.

${ }^{153}$ Laurence Tribe, American Constitutional Law (West Publishing Company, 1978) 859.

154 Amselem, supra note 129 at para 51.

155 It is worth noting the idea of "alternative burdens" suggested by Adam Kolber - see "Alternative Burdens on Freedom of Conscience” (2010) 47 San Diego L. Rev. 919. Kolber suggests that where alternatives are offered by government, for those such as conscientious objectors, they might even be more onerous, as a way to help ensure sincerity (at 928ff).

156 Maurice, supra note 135 at para 15. 
Maurice was decided before the Supreme Court of Canada decision in Amselem, which held that a "nexus to religion" coupled with a "sincerity of belief" is sufficient to ground a claim of religious freedom. The actual nature of the belief is left to the subjective determination of the individual, and may, in some cases, be unreasonable. Do the same concerns arise in the case of conscience-based freedoms? Since, by definition, there is no "nexus to religion" in conscience-based freedoms, the Amselem test might just collapse into a simple requirement of sincerity in any conscience-based claim. In doing so, however, the potential for false claims increases. In Williamson, Lord Nicholls referred to the Amselem test and adapted it for a conscience-based freedom. By equating a conscience-based act with a religious one - it must be of comparable importance to practices associated with religious beliefs - he addresses the need to limit conscience's scope in order to prevent floodgates from opening.

Of course, it must be recognized that compulsion, like morality, is somewhat indeterminate. This presents an obstacle for some whistleblowing situations. Easy are those cases we described as "mandatory whistleblowing." Most corporate policies state that employees "have a duty to report." The "compensate" and "tolerate" are more difficult, as reporting is not compelled by law or corporate policy. In these cases, the internal voice compelling a whistleblower to "do the right thing" can be strong. The compulsion is thus subjective, but it may be grounded in one or more of a number of rationales: idealism; an abiding sense of truth or honour; naivete; morality; personality; or trust. However, we feel that the varied protection offered by morality, compulsion and sincerity should alleviate most of the difficulties of using freedom of conscience to support whistleblowers. That leaves us to consider the final question: "why conscience" given the plethora of other constitutional protections offered by the Charter? 


\section{(c) Overlapping Rights and Freedoms}

One strong objection to creating a fully independent freedom of conscience is that it is unnecessary, adding little to the broad scope of Charter rights and freedoms already identified and developed. Thus, the argument goes, religious and expressive freedoms (such as thought, belief and expression) under s. 2, coupled with rights to liberty and equality under ss. 7 and 15, provide a full panoply of constitutionalized human rights protection. There are two short answers to this. Firstly, all rights and freedoms deserve as much protection as possible, in whatever form works. Secondly, and more importantly, is to turn the question around and ask why religious freedom should be singled out at the expense of a broader freedom of conscience. The advantages to broadening the freedom through the development of conscience, where appropriate, seem to be plain. The words in the Charter should all be treated with equal force.

The mere fact that the Charter provisions sometimes overlap is not sufficient reason to ignore express words, such as "conscience", found in the text. Freedom of religion and conscience will often overlap. Conscience can overlap with thought, belief and opinion. So can freedom of conscience and liberty under s. $7 .{ }^{157}$ Yet religion and liberty can also very easily clash, although little has been made of this. In Blencoe v. B.C. (Human Rights Commission) the Supreme Court of Canada was asked whether the Charter applied to an administrative tribunal and the scope of "liberty" in the context of s. 7 of the Charter. ${ }^{158}$ The Court gave a broad reading to liberty:

The liberty interest protected by s. 7 of the Charter is no longer restricted to mere freedom from physical restraint. Members of this Court have found that "liberty" is engaged where state compulsions or prohibitions affect important and fundamental life choices...In our free

157 See Wilson J. in Morgentaler, supra note 130, for evidence of this.

158 [2000] 2 S.C.R. 307 
and democratic society, individuals are entitled to make decisions of fundamental importance free from state interference...the liberty interest protected by s. 7 must be interpreted broadly and in accordance with the principles and values underlying the Charter as a whole and that it protects an individual's personal autonomy...[T] he right to liberty in s. 7 protects the individual's right to make inherently private choices... ${ }^{159}$

The Court then cited with approval a passage from Godbout v. Longueuil (City) that affirmed s. 7's broad scope, containing within its ambit the "right to an irreducible sphere of personal autonomy" over matters which by their very nature "implicate basic choices going to the core of what it means to enjoy individual dignity and independence." ${ }^{160}$ If freedom of conscience contributes little to the right to liberty in s. 7 , then so does religion. One can compare the passages from Blencoe and Godbout above as if they were discussing religion. Religious belief is something that allows one to make "inherently private choices" that go to the "core of what it means to enjoy individual dignity and independence;" religion deals with "important and fundamental life choices" that allow one to "live his or her life" in the way he or she chooses. If s. 7 is interpreted to include the exercise of religious freedom, it would make s. 2(a) entirely redundant.

There is a need to retain all the fundamental freedoms in s. 2. They differ from the legal rights set out in s. 7 and elsewhere because freedoms, as compared to rights, recognize a positive element that respects the autonomy and individuality of all humans and permits it to flourish. Fundamental freedoms are not subject to the internal limits of s. 7's 'in accordance with fundamental justice." To argue that freedom of conscience is unnecessary due to the protection of liberty in s. 7 , makes little sense unless one is prepared to accept that freedom of religion as equally unnecessary.

Mindful of these constraints, the concluding step in the argument is to elaborate a made-in-Canada approach to assessing freedom of conscience.

159 Ibid at paras. 49, 51.

160 Ibid at para. 51, citing Godbout v. Longueuil (City) [1997] 3 S.C.R. 844 at para 66. 


\section{Conclusion}

In Amselem, the Supreme Court of Canada spelled out a two-stage, three-component

test for establishing a freedom of religion claim. An individual must first show that

he or she has a practice or belief, having a nexus with religion, which calls for a particular line of conduct, either by being objectively or subjectively obligatory or customary, or by, in general, subjectively engendering a personal connection with the divine or with the subject or object of an individual's spiritual faith, irrespective of whether a particular practice or belief is required by official religious dogma or is in conformity with the position of religious officials; and (2) he or she is sincere in his or her belief. ${ }^{161}$

Then,

that the impugned contractual or legislative provision (or conduct) interferes with his or her ability to act in accordance with his or her religious beliefs in a manner that is more than trivial or insubstantial. ${ }^{162}$

Our proposed approach for a broader freedom seeks only to modify this test to fit within a framework more suited to conscience. The three parts would require claimants to show, in the face of laws or conduct requiring him or her to act contrary to conscience, that

(1) he or she has a belief of a moral nature (defined broadly as described above), or a belief governing his or her perception of themselves, humankind, or nature, which either calls for a particular line of conduct that is subjectively obligatory or is a demonstrably fundamental decision that goes to the heart of who he or she is (in other words, is comparable with religious belief);

(2) he or she is sincere in his or her belief; and

(3) the impugned provision (or conduct), in purpose or effect, interferes with his or her ability to act in accordance with his or her belief in a manner that is not trivial or insubstantial.

161 Amselem, supra note 129 at para 56.

162 Ibid at para 59 (emphasis in original). 
Where a law imposes on such personal decisions in accordance with the above, it should be found to breach the fundamental freedom of conscience. This allows for an approach to freedom of conscience that strives to separate legitimate from illegitimate claims: arguments made by fox hunters in Countryside Alliance, ${ }^{163}$ for example, should be able to be distinguished from those put forward by women seeking an abortion. While both take a similar form each arise from laws that impinge on one's ability to act on a desire - as much as anything, hunting animals feels very different from aborting a child. In our view, hunting is not something we should protect through freedom of conscience, while abortion is. Hunters are not, to our minds, engaged in an activity or behaviour that is of "comparable importance to religion." ${ }^{164}$ Hunting is an activity easily abstained from. ${ }^{165}$ Determining whether to have an abortion, by contrast, is a quintessentially "moral decision." Criminal prohibitions against abortion treat women as a "means to an end," denying them of their "essential humanity.", Hunting regulations do no such thing.

Having developed the concept of freedom of conscience, the application of it to whistleblowers is fairly straightforward. In simple terms, legitimate whistleblowers should be thought of as performing a service important enough to garner constitutional protection under freedom of conscience. The whistleblower faces many of the same obstacles and difficulties as do women who choose to abort, or those who decline to eat meat for moral reasons. Whistleblowers feel compelled to act, after difficult reflection upon the issue of the right course of action, and weighing the consequences, they usually proceed in the face of likely retaliation. As we noted earlier, it is the aspect of doing "good" or "justice" - in the face of a strong potential for retaliation, in any form and degree - which most connects

163 Countryside Alliance and others v. HM Attorney General and others [2005] EWHC 1677 (QBD (Divisional Court).

164 Ibid at para 249.

165 Ibid.

166 Morgentaler, supra note 130 at para. 253. 
whistleblowing with conscience. At the same time, freedom of conscience provides an effective analytical tool with which to assess genuine whistleblowing: a person who proceeds to blow the whistle without engaging in a conscience-based assessment prior to doing so, should not be protected. The parallels with, on the one hand, hunting, and on the other, abortion and vegetarianism, are strong - a person who blows the whistle motivated by malice is little different from a person wishing to fox hunt. Neither should be able to claim that their behaviour fits our model of freedom of conscience. In contrast, a whistleblower who claims an inner compulsion to "do the right thing" by publicizing a superior's wrongdoing, is acting much like a woman who agonizes with her spouse about the need to abort a child or the vegetarian who cannot eat meat. In those cases, the decision requires the same moral squint that allowed Gandhi to take on an entire nation. By tying whistleblowing to conscience, through adopting legislative and policy choices that engage this universal aspect of humanity, some of the concerns inherent in whistleblowing will be reduced.

A robust understanding of conscience could change the nature of the constitutional freedom envisioned under s. 2(a) of the Charter. By elevating conscience as the paramount morally-based, individual freedom, and reserving religious freedom for its more natural fit with communal practices, a uniquely Canadian approach to the problem of belief-based claims could be crafted. Since a central commitment of our Charter, as the Supreme Court of Canada noted, seeks to protect the dignity and vulnerability of all persons, and to treat all individuals as equals, a strong form of freedom of conscience would allow us to be fair in all matters of ultimate destiny, by protecting religious adherents and morally-bound nonreligious individuals alike. To rely on one's legally-protected conscience is to assert one's fundamental integrity and dignity, on a matter that is unconditionally serious, non-negotiable and binding. It is, in essence, religion writ small. 
Freedom to blow the whistle, and to be effectively free from retaliation supported by the force of law, fit seamlessly within this enhanced idea of conscience. We believe that whistleblowing, like other morally-based activities, may well be viewed in terms of a constitutionally protected right with the requisite government apparatus accorded other Charter rights. Honest whistleblowers deserve no less. 